\title{
PENGEMBANGAN E-MODUL KIMIA BERBASIS STEM DENGAN PENDEKATAN ETNOSAINS
}

\author{
Eris Nurhayati ${ }^{1 *}$, Yayuk Andayani ${ }^{2}$, Aliefman Hakim ${ }^{3}$ \\ ${ }^{12}$ Program Studi Magister Pendidikan IPA, Universitas Mataram, Indonesia \\ ${ }^{2}$ Program Studi Pendidikan Kimia, Universitas Mataram, Jalan Majapahit No. 62 Mataram, \\ Nusa Tenggara Barat, Indonesia. \\ * Corresponding author: Eris_nurhayati@guruinovatif.com
}

Received : 1 Juli 2021

Accepted : 25 Juli 2021

Published: 14 Agustus 2021 doi: 10.29303/cep.v4i2.2768

\begin{abstract}
Abstrak
Penelitian ini bertujuan untuk menghasilkan e-modul kimia berbasis STEM dengan pendekatan etnosains yang valid dan praktis. Pengembangan e-modul didasarkan pada model 4D dari Thiagarajan, S. Semmel \& Semmel yang dimodifikasi menjadi tiga tahap yaitu define, design, dan develop. Uji validitas e-modul kimia dilakukan oleh ahli bidang Pendidikan Kimia dan uji kepraktisan dengan responden guru dan peserta didik dilakukan dengan menggunakan angket. Hasil penelitian menunjukkan bahwa e-modul kimia berbasis STEM dengan pendekatan etnosains dalam kategori layak dan praktis digunakan dalam pembelajaran dengan perolehan skor berturut-turut sebesar $87 \%$ dan $86,2 \%$.
\end{abstract}

Kata Kunci: pengembangan, e-modul kimia, etnosains, STEM.

\section{Development of Stem-Based Chemical E-Modules with Etnoscience Approach}

\begin{abstract}
This study aims to produce a STEM-based chemistry e-module with a valid and practical ethnoscience approach. The development of the e-module is based on a 4D model from Thiagarajan, $S$. Semmel \& Semmel which was modified into three stages, namely define, design, and develop. The test of the validity of the chemical e-module was carried out by experts in the field of Chemistry Education and the practicality test with teacher and student respondents was carried out using a questionnaire. The results showed that the STEM-based chemistry e-module with an ethnoscience approach in the feasible and practical category was used in learning with a score of $87 \%$ and $86.2 \%$, respectively.
\end{abstract}

Keywords: development, chemistry e-modul, etnoscience, STEM.

\section{PENDAHULUAN}

Indonesia merupakan salah satu negara dengan tingkat keberagaman yang sangat tinggi (Lestari, 2015; Pitoyo, 2017). Kondisi sosial budaya maupun geografi Indonesia yang heterogen menjadi latar belakang yang kuat untuk mengaitkan budaya dengan pembelajaran sains. Menurut Sudarmin (2015), pembelajaran dapat dilihat dari sisi budaya dan konteks ilmiah berdasarkan perspektif multikultural

Pembelajaran sains yang dilaksanakan selama beberapa dekade terakhir lebih banyak mengadopsi sistem pendidikan negara barat yaitu Eropa dan Amerika. Sedangkan kebudayaan dan pembelajaran negara bagian barat, relatif modern dan tidak mengangkat budaya lokal..
Pembelajaran dengan pendekatan etnosains merupakan pembelajaran dengan mengaitkan budaya lokal, ilmu pengetahuan asli (indegenous knowledge) dan pengetahuan ilmiah telah dikembangkan di berbagai negara (Sudarmin, 2017).

Pengetahuan asli adalah salah satu studi dalam etnosains, yang pengetahuannya berasal dari masyarakat. Pengetahuan asli dapat diuji kebenarannya melalui studi pustaka dan penjelasan yang bersifat ilmiah, sehingga dapat digunakan sebagai salah satu sumber pembelajaran sains yang bersifat otentik. (Turiman, 2012; Izzah, 2020). Etnosains merupakan pengetahuan lintas disiplin, yang merupakan kolaborasi antara berbagai bidang pelajaran baik itu sains, sosial maupun 


\section{Chemistry Education Practice, 4 (2), 2021 - 107}

Nurhayati, Andayani, Hakim

matematika. Pada saat yang sama, etnosains semakin bersifat transdisipliner (Laar, 2017). Pembelajaran berbasis STEM menumbuhkan sumber daya manusia yang kritis dan mempunyai kompetensi untuk bersaing di abad ke-21 (Sumarni, 2018). STEM merupakan integrasi yang bermakna antara sains, pengetahuan matematika, teknologi seta prinsip engineering (Gonzales, 2012; Justin,2017)

Di dalam kurikulum 2013, tertuang bahwa budaya dan kearifan lokal dapat berperan dalam mendukung mata pelajaran IPA (Kemdikbud, 2014; 2018). Implikasinya, seorang pendidik harus merangsang peserta didik dengan menggunakan budaya dan kearifan lokal sebagai media untuk pembelajaran siswa, dengan memanfaatkan teknologi sebagai perantaranya. Budaya, seni, serta kearifan lokal yang terdapat pada masyarakat sekitar dapat merangsang rasa keingintahuan dan kreatifitas siswa. Secara alamiah dan naluriah peserta didik bertingkah laku sebagai seorang ilmuwan, yang tidak hanya mengenal sesuatu sebagai teori, tetapi mampu mengkaitkannya dengan kehidupan yang ada di sekitarnya. Menurut Yuliana (2017), dengan mempelajari kekhasan yang terdapat di dalam suatu masyarakat maka siswa dapat memahami peristiwa alam yang berada di sekitarya dan dapat mengaitkannya dengan bidang yang dipelajari oleh siswa tersebut.

Berdasarkan penelitian Andayani, dkk (2021) dari 113 responden guru kimia provinsi Nusa Tenggara Barat, sebanyak 69,03\% belum pernah membaca dan menemukan modul yang menggunakan pendekatan etnosains dalam pembelajaran. Secara umum dalam penelitian tersebut disampaikan bahwa guru-guru berpendapat, bahwa penting untuk mengikutsertakan budaya di dalam pelajaran kimia.

Di sisi lain, saat ini manusia tidak bisa dipisahkan dengan teknologi. Teknologi digital dan internet telah menguasai seluruh elemen masyarakat dan seluruh bidang kehidupan, termasuk di dalamnya adalah bidang pendidikan. Teknologi berada di dalam genggaman, tidak hanya menjadi slogan. Manusia dapat menggunakan teknologi untuk hal-hal yang dikehendaki. Penggunaan teknologi dalam bidang pendidikan dikemas dalam mobile learning media, yang memanfaatkan peran alat elektronik mobile untuk menyampaiakan bahan pembelajaran, sehingga peserta didik memiliki waktu dan tempat yang flekesibel untuk mengakses informasi yang disampaikan oleh guru. (Wijayanti, 2019; Tresnawari, 2019). Bagian dari electronic based e-learning yang pembelajarannya memanfaatkan perangkat berupa elektronik sebagai media dalam berkomunikasi dan mnyampaikan informasi adalah e-modul (Dimhad, 2015; Nadhifah, 2017).

Bidang studi kimia adalah salah satu bidang yang dianggap sulit di tingkat SMA. Kemajuan teknologi multimedia pembelajaran memungkinkan siswa mempelajari ilmu kimia dalam bentuk modul elektronik (Nugroho, 2015). Bahan ajar berupa modul elektronik, memiliki beberapa keunggulan, diantaranya memudahkan siswa untuk mendapatkan informasi dengan menggunakan perangkat elektronik yang dimiliki oelh siswa tersebut, baik berupa komputer PC, laptop, i pad, maupun telefon genggam. dimana saja dan kapan saja, sehingga memungkinkan siswa memperoleh penguasaan materi pelajaran secara tuntas (S. Perinpasingan, 2014).

Di dalam penelitian ini telah disusun emodul kimia berbasis STEM dengan pendekatan etnosains. Ada beberapa tema etnosains kontekstual yang diangkat di dalam e-modul ini. Untuk mendapatkan e-modul yang lebih baik, maka perlu dilakukan uji coba kelayakan dan kepraktisan. E-Modul kimia berbasis STEM dengan pendekatan etnosains ini diharapkan dapat digunakan dalam pembelajaran sehingga dapat menghubungkan pengetahuan sains asli peserta didik dengan pengetahuan sains ilmiah di sekolah.

\section{METODE}

Format yang digunakan dalam e-modul ini adalah flipbook. Jenis penelitian yang digunakan dalam pengembangan e-modul yaitu penelitian dan pengembangan (Research and Development). Pengembangan e-modul didasarkan pada model 4D dari Thiagarajan, S. Semmel \& Semmel (1974) yang dimodifikasi menjadi tiga tahap yaitu define (pendefisian) adalah tahap untuk menganalisis kebutuhan terkait pengembangan; design (perancangan) adalah tahap untuk merancang format dan isi dari e-modul sesuai dengan kebutuhan guru dan peserta didik termasuk dalam pemilihan format e-modul, yang memiliki tampilan menarik, mudah diakses serta disebarluaskan. Tahapan yang ketiga adalah develop (pengembangan), yaitu tahapan validasi ahli dan revisi untuk mendapatkan modul yang valid dan layak untuk digunakan dan disebarluaskan. Uji validitas emodul kimia meliputi uji kelayakan isi dan 
kepraktisan. Uji kelayakan dilakukan oleh ahli dalam bidang Pendidikan. Berikut rumusan untuk menguji kelayakan.

Keterangan:

$$
P=\frac{\sum X}{\sum X i} \times 100 \%
$$

$\mathrm{P}=$ persen kelayakan

$\sum \mathrm{X}=$ total skor yag diperoleh

$\sum \mathrm{Xi}=$ skor maksimal

Kriteria kelayakan pengembangan disajikan dalam tabel 1.

Tabel 1. Kriteria Penskoran Kelayakan Pengembangan

\begin{tabular}{cc}
\hline $\begin{array}{c}\text { Persen Hasil } \\
\text { Penskoran }(\%)\end{array}$ & Tingkat Kelayakan \\
\hline $81-100$ & Sangat layak \\
\hline $61-80$ & Layak \\
\hline $41-60$ & Cukup layak \\
\hline $21-40$ & Kurang layak \\
\hline $0-20$ & Tidak layak \\
\hline
\end{tabular}

(Arikunto, 2010)

Persen hasil penskoran yang diperoleh menentukan tingkat kelayakan dari hasil pengembangan. Sesuai dengan Tabel 1, suatu hasil pengembangan layak untuk digunakan apabila mendapatkan skor dari $41 \%$ sampai dengan $100 \%$ dengan kriteria cukup layak, layak dan sangat layak..

Data dari uji kepraktisan diperoleh melalui tanggapan atau respon peserta didik dan guru kimia terhadap e-modul kimia yang dikembangkan. Data diperoleh dengan menggunakan skala likert dalam bentuk skor satu (nilai terendah) sampai dengan 4 (nilai tertinggi). Berikut rumusan untuk Uji Kepraktisan:

$$
\% N=\frac{\text { Jumlah skor yang diperoleh }}{\text { jumlah skor maksimal }} \times 100 \%
$$

Penentuan konversi skor tanggapan peserta didik menggunakan kriteria pada tabel 2.

Tabel 2. Kriteria Penskoran Tanggapan Peserta Didik

\begin{tabular}{cc}
\hline \% Kepraktisan & Kriteria \\
\hline $80 \%-100 \%$ & Praktis \\
\hline $60 \%-79 \%$ & Cukup Praktis \\
\hline $50 \%-59 \%$ & Kurang Praktis \\
\hline$<50 \%$ & Tidak Praktis \\
\hline
\end{tabular}

(Mardikaningtyas, 2016)

\section{HASIL DAN PEMBAHASAN}

Pada penelitian ini dihasilkan e-modul kimia berbasis STEM dengan pendekatan etnosains. Pelaksanaan kegiatan penelitian ini terdiri dari tiga tahap, yaitu tahapan define, design dan develop. Tahap define, dilakukan dengan mengumpulkan informasi mengenai seberapa banyak guru di Provinsi NTB yang mengikutsertakan budaya di dalam pelajaran kimia serta seberapa besar kesiapan siswa menggunakan teknologi dalam pembelajaran. Hasilnya 69,03 \% guru NTB belum mengintegrasikan budaya ke dalam pembelajaran kimia (Andayani, dkk., 2021). Sedangkan melalui angket e-readiness yang disebarkan ke 200 peserta didik pada sekolah tingkat menengah, hasil dari skor e-readiness siswa berada pada skala 3 dari 4 skala. Artinya, siswa telah siap melaksanakan pembelajaran dengan menggunakan teknologi sebagai perantara. Selain itu pada tahapan define juga dilakukan pemilihan tema yang sesuai untuk dibahas di dalam e-modul. E-modul terdiri dari 3 tema, yang diangkat dari kekhasan yang dimiliki oleh wilayah di area Pulau Lombok. Judul tema yang diangkat yaitu "Etnokimia Nata de Aren", "Etnokimia Garam Cendi Manik" dan "Etnokimia Tambang Emas di Sekotong". Masing-masing tema yang diangkat berisi tema kontekstual sains asli masyarakat yang digali lebih mendalam dari sisi ilmiah. Di dalam 1 tema dapat dikaitkan dengan beberapa Kompetensi Dasar (KD) mata pelajaran kimia timgkat SMA.

Pada tahapan design, dilakukan perancangan e-modul untuk mendapatkan format e-modul yang berfungsi sebagai modul pelengkap pembelajaran. E-modul berbasis STEM dengan pendekatan etnosains ini merupakan suatu modul elektronik yang mengangkat budaya lokal, dikaitkan dengan ilmu kimia yang diintegrasikan dengan sains, teknologi, engineering dan matematika. Melalui pembelajaran STEM, peserta didik distimulus untuk piawai dalam memecahkan masalah, mampu merancang atau menemukan hal baru, memiliki kepekaan untuk meningkatkan kapasitas dirinya serta memiliki penguasaan teknologi yang baik. (Suwarma, 2015).

E-modul yang digunakan dalam penelitian ini menggunakan flipbook yang memiliki kelebihan tampilan menarik, mudah diakses dan disebarluaskan. E-modul dilengkapi dengan aktivitas dan lembar kerja STEM, berisi aktivitas yang dapat dipilih sesuai kesepakatan guru dan siswa untuk mendukung kompetensi dasar yang sedang dipelajari. Selain itu, E-modul juga materi kimia, menyajikan link materi yang dapat dipelajari yang berkaitan dengan kegiatan etnosains dan STEM yang sedang dilaksanakan. 


\section{Chemistry Education Practice, 4 (2), 2021 - 109}

Nurhayati, Andayani, Hakim

Integrasi sains asli ke dalam sains sekolah dapat meningkatkan kebanggaan dan ketertarikan peserta didik terhadap materi kimia (Utari, dkk, 2020).

Pada tahapan develop, dilakukan validasi isi berupa uji kelayakan yang dilakukan oleh ahli dalam bidang pendidikan. Setelah itu itu dilakukan revisi sesuai dengan masukan validator ahli untuk mendapatkan modul yang valid dan layak untuk digunakan dan disebarluaskan. Tabel 3 merupakan rangkuman saran dan perbaikan dari validator ahli.

Tabel 3. Saran Ahli dan Hasil Perbaikan E-Modul

\begin{tabular}{|c|c|c|}
\hline No & Saran & Perbaikan \\
\hline 1 & $\begin{array}{l}\text { Pada bagian petunjuk penggunaan } \\
\text { modul, sebaiknya menampilkan } \\
\text { petunjuk untuk guru dan siswa }\end{array}$ & $\begin{array}{l}\text { Petunjuk penggunaan e-modul sudah disesuaikan } \\
\text { peruntukan bagi guru dan siswa }\end{array}$ \\
\hline 2 & $\begin{array}{l}\text { Judul kegiatan sebaiknya diganti } \\
\text { dengan judul tema pada masing- } \\
\text { masing kegiatan }\end{array}$ & $\begin{array}{l}\text { Judul kegiatan sudah disesuaikan dengan judul tema } \\
\text { pada masing-masing kegiatan }\end{array}$ \\
\hline 3 & $\begin{array}{l}\text { Pada tujuan pembelajaran sebaiknya } \\
\text { disampaikan tujuan umum terlebih } \\
\text { dahulu sebelum menyampaikan tujuan } \\
\text { pada masing-masing bidang, dan } \\
\text { iletakkan di bagian depan }\end{array}$ & $\begin{array}{l}\text { Tujuan pembelajaran dituliskan tujuan umum terlebih } \\
\text { dahulu baru setelah itu ditulis tujuan pada masing- } \\
\text { masing bidang, dan posisinya sudah diletakkan di } \\
\text { bagian depan }\end{array}$ \\
\hline 4 & $\begin{array}{l}\text { Sebaiknya dimunculkan peta kimia } \\
\text { yang menghubungkan tema dengan } \\
\text { materi yang berkaitan }\end{array}$ & $\begin{array}{l}\text { Peta kimia yang menghubungkan tema dengan materi } \\
\text { yang berkaitan sudah dimunculkan }\end{array}$ \\
\hline 5 & $\begin{array}{l}\text { Perbanyak gambar yang lebih } \\
\text { menunjukkan identitas mata pelajaran, } \\
\text { yaitu kimia }\end{array}$ & $\begin{array}{l}\text { Sudah menampilkan gambar yang menunjukkan } \\
\text { proses kimia yang berkaitan dengan tema }\end{array}$ \\
\hline 6 & Lengkapi e-modul dengan glossarium & E-modul sudah dilengkapi dengan glossarium. \\
\hline
\end{tabular}

Berdasarkan hasil uji kevalidan diperoleh bahwa e-modul yang dikembangkan dalam kategori valid dan layak digunakan dalam pembelajaran dengan skor rata-rata sebesar $87 \%$. Berikut rangkuman hasil validasi e-modul kimia pada tabel 4.

Tabel 4. Data Hasil Validasi E-Modul Kimia Berbasis STEM dengan Pendekatan Etnosains

\begin{tabular}{clcc}
\hline No & \multicolumn{1}{c}{ Aspek Penilaian } & Skor Validasi & Kriteria \\
\hline 1. & Kesesuaian dengan KI, KD & $90 \%$ & Sangat Layak \\
\hline 2. & Kesesuaian dengan kebutuhan peserta didik & $87 \%$ & Sangat Layak \\
\hline 3. & Keakuratan materi & $87 \%$ & Sangat Layak \\
\hline 4. & Kemutakhiran materi & $87 \%$ & Sangat Layak \\
\hline 5. & Kebermanfaatan menambah wawasan & $83 \%$ & Sangat Layak \\
\hline 6. & Pendukung penyajian & $90 \%$ & Sangat Layak \\
\hline 7. & Penyajian pembelajaran & $82 \%$ & Sangat Layak \\
\hline 8. & Komponen Etnosains & $87 \%$ & Sangat Layak \\
\hline 9. & Komponen STEM & $93 \%$ & Sangat Layak \\
\hline & Rata-Rata & $\mathbf{8 7 \%}$ & Sangat Layak \\
\hline
\end{tabular}

Uji kepraktisan diperoleh berdasarkan data angket respon peserta didik terhadap modul yang dikembangkan. Respon peserta didik terhadap modul dinilai berdasarkan beberapa indikator yakni keterbacaan e-modul, praktikum yang disajikan, aspek materi, pembelajaran dan motivasi. Gambar 1 merupakan representasi nilai tanggapan dari masing-masing indikator pada uji kepraktisan. 


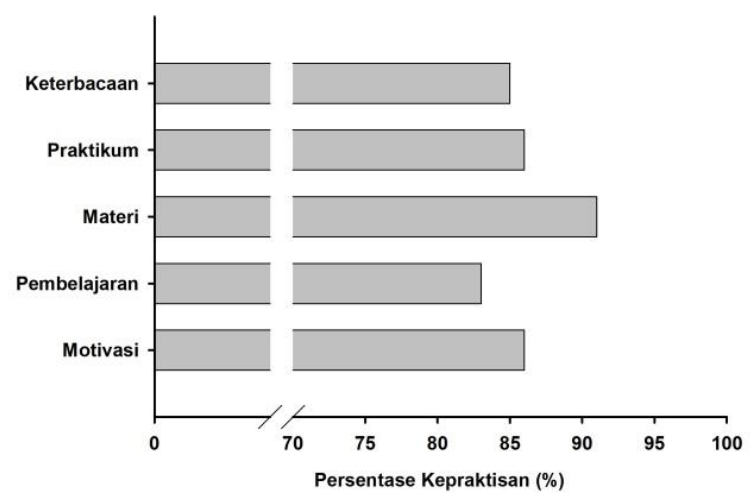

Gambar 1. Grafik Perbandingan indikator tanggapan peserta didik terhadap e-modul kimia berbasis STEM dengan pendekatan etnosains

Pada gambar tersebut menunjukkan bahwa hasil respon peserta didik terhadap modul sangat baik. Dari lima indikator yang diberikan penilaian menunjukkan respon positif, dengan rata-rata hasil uji kepraktisan sebesar 86,2\%, artinya modul ini praktis digunakan dalam pembelajaran.

Data persentase tertinggi ditunjukkan pada penyajian materi. Peserta didik diberikan kebebasan memilih model materi pembelajaran secara mandiri, baik dalam bentuk video pembelajaran, maupun dalam bentuk teks. Selain itu penyajian materi juga dilengkapi dengan hypertext yang memudahkan peserta didik untuk mendapatkan informasi lebih lengkap yang terhubung di dalam jaringan Hypertext ditandai dengan teks dicetak berwarna biru untuk menunjukkan bahwa ada tambahan informasi yang diberikan pada text tersebut.

Pada kategori pembelajaran menunjukkan persentase respon yang paling rendah bila dibandingkan dengan indikator yang lainnya, meskipun masih di dalam kriteria praktis.

\section{SIMPULAN}

Berdasarkan hasil penelitian dan pembahasan dapat disimpulkan bahwa e-modul kimia berbasis STEM dengan pendekatan etnosains yang dikembangkan memenuhi persyaratan kelayakan dan kepraktisan, sehingga modul tersebut dapat digunakan dalam pembelajaran kimia.

\section{DAFTAR PUSTAKA}

Andayani, Y., Anwar, Y. A. S., \& Hadisaputra, S. (2021). Pendekatan Etnosains dalam Pelajaran Kimia Untuk Pembentukan
Pembelajaran berbasis STEM dengan pendekatan etnosains adalah hal yang baru bagi peserta didik. Integrasi pengetahuan asli (indigenous knowledge) ke dalam ranah ilmu pengetahuan dalam hal ini sains, teknologi, teknik dan matematika merupakan sesuatu yang sebelumnya tidak pernah dilakukan oleh peserta didik. Hal ini merupakan tantangan baik bagi tenaga pendidik maupun peserta didik untuk lebih jeli membaca fenomena yang nampak di alam. Bahwa ada sisi ilmu pengetahuan dari halhal yang terbiasa dilakukan atau sekedar dilihat maupun diketahui oleh peserta didik dalam kehidupan sekitar. Harapannya, perubahan dalam proses pembelajaran lebih ditekankan pada pembelajaran kontekstual dan menyenangkan bagi siswa. Selain itu, penerapan aspek budaya penting diintegrasikan dalam proses pembelajaran untuk mempertahankan identitas bangsa Indonesia dan membentuk karakter siswa (Andayani, dkk., 2021)

Berdasarkan data uji kelayakan oleh ahli serta respon peserta didik dalam uji kepraktisan, e-modul kimia berbasis STEM dengan pendekatan etnosains layak dan praktis digunakan dalam pembelajaran. Pengembangan e-modul kimia berbasis STEM dengan pendekatan etnosains ini mampu menjadi alternatif bahan ajar yang membantu guru dan siswa untuk memanfaatkan teknologi sebagai sarana belajar dan menanamkan rasa cinta terhadap kebudayaan lokal. Dengan mengaplikasikan STEM-etnosains ke dalam pembelajaran memberikan dampak yang positif terhadap peserta didik berupa munculnya kreatifitas, meningkatnya ketrampilan berpikir kritis, kemampuan kolaboratif dan komunikatif. (Suwarna, 2015; Winarni, dkk., 2016)

Karakter Siswa: Tanggapan Guru Kimia di NTB. Jurnal Pijar Mipa, 16(1), 39-43.

Arikunto, Suharsimi. (2006). Dasar-dasar Evaluasi Pendidikan. Jakarta: Bumi Aksara.

Dimhad. 92015). Penggunaan E-Modul Interaktif Melalui Pembelajaran Berbasis Masalah Untuk Meningkatkan Pemahaman Konsep Sistem Saraf, Kemampuan Generik Sains Dan Berpikir Kritis.

Gonzalez, H. B., \& Kuenzi, J. J. (2012, August). Science, technology, engineering, and mathematics (STEM) education: A 
primer. Washington, DC: Congressional

Research Service, Library of Congress.

Izzah, S. N., Sudarmin, S., \& Prasetyo, A. P. B. (2020, June). Identification of the indigenous science concepts in the batikmanufacturing process to develop STEM integrated ethnoscience learning. In Journal of Physics: Conference Series (Vol. 1567, No. 4, p. 042032). IOP Publishing.

Powell, J. J., \& Dusdal, J. (2017). Science production in Germany, France, Belgium, and Luxembourg: Comparing the contributions of research universities and institutes to science, technology, engineering, mathematics, and health. Minerva, 55(4), 413-434.

Kemendikbud. (2014). Materi Pelatihan Implementasi Kurikulum 2013 di tahun 2014.

Kemendikbud. (2018). Permendikbud No. 37 Tahun 2018 Tentang Kompetensi IntiKompetensi Dasar SD MI SMP SMA.

Van Laar, E., Van Deursen, A. J., Van Dijk, J. A., \& De Haan, J. (2017). The relation between 21 st-century skills and digital skills: A systematic literature review. Computers in human behavior, 72, 577588.

Lestari, G. (2016). Bhinnekha Tunggal Ika: Khasanah Multikultural Indonesia Di Tengah Kehidupan SARA. Jurnal Ilmiah Pendidikan Pancasila Dan

Kewarganegaraan, 28(1).

Mardikaningtyas, D. A., Ibrohim, I., \& Suarsini, E. (2016). Pengembangan Pembelajaran Pencemaran Lingkungan Berbasis Penelitian Fitoremediasi untuk Menunjang Keterampilan Ilmiah, Sikap Peduli Lingkungan dan Motivasi Mahasiswa pada Matakuliah Dasar-Dasar Ilmu Lingkungan. Jurnal Pendidikan: Teori, Penelitian, dan Pengembangan, 1(3), 499-506.

Nadhifah, N., \& Muslih, I. (2017). Peningkatan Kapasitas Guru dalam Mengembangkan Media Pembelajaran Information and Communication Technology (ICT) di Madrasah Ibtidaiyah Thoriqul Huda Randuharjo Pungging Mojokerto. Modeling: Jurnal Program Studi PGMI, 4(2), 172-191.

Nazir. (2011). Metode Penelitian. Bogor: Ghalia Indonesia
Nugroho, K. M. (2015). Pengembangan EModul Kimia Berbasis Problem Solving Dengan Menggunakan Moodle Pada Materi Hidrolisis Garam Untuk Kelas XI SMA/MA SEMESTER II (Doctoral dissertation, UNS (Sebelas Maret University)).

Pitoyo, A. J., \& Triwahyudi, H. (2017). Dinamika perkembangan etnis di Indonesia dalam konteks persatuan negara. Populasi, 25(1), 64-81.

Suwarma, I. R., Astuti, P., \& Endah, E. N. (2015). "Balloon Powered Car" Sebagai media pembelajaran IPA berbasis STEM (Science, Technology, Engineering and Mathematics). Prosiding Simposium Nasional Inovasi dan Pembelajaran Sains, 373-376.

Sugiyono. (2008). Metode Penelitian Pendidikan Pendekatan Kuantitatif, Kualitatif dan $R \& D$, Bandung: Alfabeta

Sumarni, W. (2018). The influence of ethnoscience-based learning on chemistry to the chemistry's literacy rate of the prospective teachers. Unnes Science Education Journal, 7(2).

Sudarmin, S. (2014). Pendidikan Karakter, Etnosains dan Kearifan Lokal [Konsep dan Penerapannya dalam Penelitian dan Pembelajaran Sains].

Sudarmin, R. F. K., Nuswowati, M., \& Sumarni, W. (2017). Development of ethnoscience approach in the module theme substance additives to improve the cognitive learning outcome and student's entrepreneurship. In IOP Conference Series: Journal of Physics (Vol. 824, No. 012024, pp. 1-14).

Sumarni, W. (2016). The Reconstruction of Society Indigenous Science into Scientific Knowledge in the Production Process of Palm Sugar Woro. Journal of Turkish Science Education, 13(4), 293-307.

Sumarni, W. (2018). The influence of ethnoscience-based learning on chemistry to the chemistry's literacy rate of the prospective teachers. Unnes Science Education Journal, 7(2).

Perinpasingam, P. T. S., Arumugam, N., Subramaniam, S., \& Mylvaganam, G. (2014). Development of a Science module through Interactive Whiteboard. Rev. Eur. Stud., 6, 31.

Sugiyono. (2012). Metode Penelitian Kuantitatif Kualitatif Dan R \& D. Bandung: Alfabeta 


\section{Chemistry Education Practice, 4 (2), 2021 - 112}

Nurhayati, Andayani, Hakim

S.Eko Putro Widoyoko. (2009). Evaluasi Program Pembelajaran.Yogyakarta ; Pustaka Belajar

Thiagarajan, S. (1974). Instructional Development for Training Teachers of Exceptional Children. Washington DC: National Center for Improvement Educational System

Tresnawati, N., Saleh, I., Trie, D., Sudarmin, S., \& Wardani, S. (2020, April). Learning Science Through STEAM Approach (Science Technology, Engineering, Arts, and Mathematics) Integrated Ethnoscience in the Context of Batik Culture for Pre Service Teachers of Primary Education. In International Conference on Agriculture, Social Sciences, Education, Technology and Health (ICASSETH 2019) (pp. 243-246). Atlantis Press.

Turiman, P., Omar, J., Daud, A. M., \& Osman, K. (2012). Fostering the 21st century skills through scientific literacy and science process skills. Procedia-Social and Behavioral Sciences, 59, 110-116.

Utari, R., Andayani, Y., \& Savalas, L. R. T. (2020). Pengembangan modul kimia berbasis etnosains dengan mengangkat kebiasaan petani garam. Jurnal Pijar Mipa, 15(5), 478-481.

Wijayanti, D. M., Ahmadi, F., \& Sarwi, S. (2019). Keefektifan Mobile Learning Media Bermuatan Ethnoscience terhadap Hasil Belajar Siswa Sekolah Dasar. MODELING: Jurnal Program Studi PGMI, 6(2), 129-136.

Winarni, J., Zubaidah, S., \& Koes, S. (2016). STEM: apa, mengapa, dan bagaimana. Prosiding Semnas Pend IPA Pascasarjana UM, 1, 976-984.

Yuliana, I. (2017). Pembelajaran berbasis etnosains dalam mewujudkan pendidikan karakter siswa sekolah dasar. Jurnal Pendidikan dan Pembelajaran Sekolah Dasar, 1(2), 98-106. 